Portland State University

PDXScholar

3-2021

\title{
COUNTER 5: Lessons Learned and New Insights Achieved
}

\author{
Jill Emery \\ Portland State University, jemery@pdx.edu \\ Lorraine Estelle \\ COUNTER
}

Stephanie J. Adams

Tennessee Technological University

Follow this and additional works at: https://pdxscholar.library.pdx.edu/ulib_fac

Part of the Collection Development and Management Commons Let us know how access to this document benefits you.

\section{Citation Details}

Emery, Jill; Estelle, Lorraine; and Adams, Stephanie J., "COUNTER 5: Lessons Learned and New Insights Achieved" (2021). Library Faculty Publications and Presentations. 325.

https://pdxscholar.library.pdx.edu/ulib_fac/325

This Post-Print is brought to you for free and open access. It has been accepted for inclusion in Library Faculty Publications and Presentations by an authorized administrator of PDXScholar. Please contact us if we can make this document more accessible: pdxscholar@pdx.edu. 
COUNTER 5: Lessons Learned and New Insights Achieved

Jill Emery

Presenter

Lorraine Estelle

Presenter

Stephanie J. Adams

Recorder

COUNTER (Counting Online Usage of NeTworked Electronic Resources) Release 5 has brought many improvements to reporting usage of e-resources. This session covered the three main developments which are the ability to see both total and unique downloads, the default exclusion of Gold Open Access usage in Standard View reports, and the introduction of the Unique_Title metric for reporting e-book usage. Examples of the manner in which different types of e-journal and e-book usage are reported with the new metrics as well as recommendations for calculating cost per use were also provided. Detailed information on Release 5 can be found in COUNTER Foundation Class YouTube videos and the Release 5 Manual for Librarians.

KEYWORDS COUNTER, Release 5, metrics, usage statistics, usage reports, e-resources

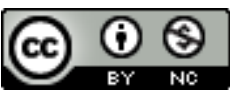

COUNTER 5: Lessons Learned and New Insights Achieved by Jill Emery, Lorraine Estelle, and Stephanie J. Adams is licensed under a Creative Commons Attribution-NonCommercial 4.0 International License. 


\section{Introduction}

Jill Emery is the Collection Development \& Management Librarian at Portland State University in Portland, Oregon. She also serves on the Project COUNTER (Counting Online Usage of NeTworked Electronic Resources) Executive Committee. Lorraine Estelle is the Director of Project COUNTER in London, United Kingdom. Ms. Emery presented the general session using presentation slides contributed by Ms. Estelle.

Emery began the session by explaining the purpose of COUNTER. COUNTER is an organization that tries to normalize usage data across content providers for librarians by working with platform providers and publishers. COUNTER 5 data is available now from the majority of content and platform providers, but COUNTER cannot mandate the use of Release 5. It is up to librarians to speak up and encourage these providers to use the latest release, so that libraries have access to comparable data.

The biggest advantage of COUNTER Release 5 is that there is no need to create a completely new release in the future. Release 5 allows for incremental changes to the data construction based on community input. These changes will be rolled out in six-month cycles. Emery continued by stating that there were a variety of changes made in Release 5, but her presentation covered three main improvements.

\section{Release 5 Improvements}

Total and Unique Downloads

Release 5 allows for differentiation between unique downloads and total HTML/PDF downloads combined. Different platforms vary in how they initially present an article to the user. Some take the user to the abstract of the article where they then have the option to view the HTML full-text or download a PDF. Other platforms take the user directly to the HTML full-text and then give the option to also download a PDF. The latter platform often leads to higher counts 
in prior releases of COUNTER reports than the former, sometimes called the platform effect, because the HTML view is always counted for the latter platform as it is the default first view. The resulting Release 5 metrics are Total_Item_Requests and Unique_Item_Requests which allow for consistent reporting of requests no matter how the platform is configured. This development in Release 5 was based on suggestions from the library community.

Emery presented a screenshot from The Royal Society e-journal platform which provides options to click on the abstract, full text, and PDF for each article. If the user clicked on each option, these actions would be reported as they appear in Table 1.

Table 1 COUNTER Release 4 and 5 Comparison

In Release 4, the reported numbers ignored the click on the abstract. The use of the abstract can be very important to a researcher in deciding whether or not they want to use the article. Release 5 provides the ability to capture that count. In this example, each click (abstract, full text, and PDF) on any of the content on the article or journal page is recorded under Total_Item_Investigations. Both the Unique_Item_Investigations and Unique_Item_Requests are one in this case because the user interacted with just this single article despite the number of ways they engaged with the content.

COUNTER recommends using Unique_Item_Requests as the metric for calculating cost per use. However, individual institutions might want to determine what to count for cost per use differently, instead using Unique_Item_Investigations or Total_Item_Investigations. Emery recommends that librarians at an institution discuss collectively what they want to count and how to count it. This discussion should be further expanded to include any consortia in order to make sure participating libraries are counting the same things and looking at the same number sets. 
Total_Item_Requests are useful for examining trends across time. Libraries can also compare usage from Release 4 reports with Total_Item_Requests from Release 5 reports.

\section{Exclusion of Gold Open Access Usage}

The exclusion of Gold Open Access usage by default in some of the Standard View reports is another improvement in Release 5 that was based on requests from the library community. Librarians expressed a need to know how much of the usage from a journal report is Open Access versus subscribed or controlled content. COUNTER created two access types that are listed in the Item Report: Controlled and OA_Gold. Controlled access refers to content that was behind a paywall and restricted to authorized users at the time of access. OA_Gold access means that at the time of the usage, the content item was available under an Open Access license - that is, freely and permanently accessible, immediately upon publication.

The ability to distinguish between Access_Types is especially useful when analyzing usage of hybrid journals, which are subscription journals in which some of the articles are Open Access. In a hybrid journal situation, an author may have paid an APC (article processing charge) in order to ensure that his or her article is published as open access. However, the library at the author's institution may have paid for a subscription to access the portion of the journal that is not open access. APCs can be paid from a variety of sources including by the author, by an institution, or by a funding agency. Only individual libraries would know the breakdown for the sources of funding at their institution. The aim of the report is for libraries to be able to determine the usage of their subscribed journals without including Open Access.

Access_Type separates usage of Gold Open Access articles from controlled (subscribed) content. Some of the Standard Views, such as the TR_J1 report automatically exclude usage of Gold Open Access content because many librarians prefer to count only the usage of articles funded by subscription payments when evaluating usage of hybrid journals. The TR_J1 is 
particularly useful for calculating cost per use for the content for which your library has paid, because it excludes Gold Open Access use. The OA_Gold Access_Type represents the Open Access articles that were funded by the author, the institution, or a funding agency. The automatic exclusion of Open Access usage is new to Release 5, so libraries may see an apparent downturn in usage in their Release 5 data from the TR_J1 report as compared to the Release 4 JR1 report. Librarians who are interested in accounting for Gold Open Access usage will need to view the TR_J3 report to see the two different Access_Types.

\section{Unique_Title Metric for E-book Usage}

When reporting e-book usage, some publishers provide access to e-books at the chapter or section level, while others provide a download of the full book. The library community expressed concerns about consistent reporting usage across e-book platforms. Because librarians purchase books, not chapters, it is important to be able to calculate cost per use at the title level regardless of the method in which the platform delivers the content. In response, COUNTER created the Unique_Title metric for Release 5, which applies to e-book usage only. This new metric allows librarians to ensure that they are comparing counts of the same units across platforms.

The three new metrics for e-books are Total_Item_Requests, Unique_Item_Requests, and Unique_Title_Requests. Most libraries will use Unique_Title_Requests to calculate cost per use in order to compare content usage across e-books and e-book packages. COUNTER recommends use of this metric as it is a fairer cross-platform comparison. However, because libraries can look at usage differently, individual institutions may prefer using a different metric for calculating cost per use. For example, a librarian may know that faculty assign just a single chapter or section, so there may be value in counting the Total_Item_Requests or the 
Unique_Item_Requests in the cost per use for their institution. Total_Item_Requests can be used to compare usage over time between Release 4 and Release 5.

In order to demonstrate how user interactions with e-book content are counted, Emery displayed a screenshot for an e-book on SpringerLink which contained five areas where users are able to click: Download book PDF, about these proceedings, single chapter title, chapter 1 PDF, chapter 2 PDF. The manner in which these clicks are counted in Release 5 is presented in Table 2.

Table 2 COUNTER Release 5 E-book Counts

Each click is counted in the Total_Item_Investigations and each download is counted in Unique_Item_Requests, but since all activity occurs within one single book, both the Unique_Title_Investigations and Unique_Title_Requests are considered one count.

The presenter also provided two sample report excerpts to further explain how e-book usage is captured in Release 5 across platforms. Platform A delivers books as single PDFs. In this example, a user has downloaded the Big Book of Chapters, which contains twenty-seven chapters all delivered together as a single item. The book is considered the Item in this case. The Standard View TR_B1 is a pre-canned summary of the Title Master Report and the Total_Item_Requests and Unique_Title_Requests for the Big Book of Chapters are each one count (See Figure 1). Note that the Section_Type attribute in Figure 1 is not shown in the Standard View.

Figure 1 Platform A Sample TR_B1

Platform B delivers books as individual chapters. In the second example, the user has downloaded all of the chapters from the Big Book of Chapters which contains twenty-seven chapters. Each chapter is delivered separately and is considered an Item. In the Standard View 
TR_B1, the Total_Item_Requests are twenty-seven and the Unique_Title_Requests are one count (See Figure 2).

Figure 2 Platform B Sample TR_B1

Emery reiterated that Unique_Title_Requests is the ideal metric for calculating cost per use. Looking at the Total_Item_Requests metric is useful for looking at trends across time for platforms that deliver chapters when comparing Release 4 and Release 5 reports. For platforms that deliver entire books as a single file, the Unique_Title_Requests metric is useful for this comparison.

COUNTER made a concerted effort to provide metrics that allow for more granularity in the understanding of usage statistics. The new metrics are intended to provide opportunities for libraries to think about the use of material in different ways and to analyze usage in ways they were previously unable to do. In Release 5, the Total_Item_Investigations metric counts the total number of times a content item or information about a content item is investigated by a user. The Total_Item_Requests metric counts the total number of times a full text (HTML, PDF, or ePub) content item was requested by a user.

Some of this granularity can be seen in how the new metrics capture different types of user behavior. In a case where a user looked at the summary of a book, such as a bibliographic record, but then decided not to request it, the Total_Item_Investigations would be one and the Total_Item_Requests would be zero. The manner in which this type of user activity was reported in Release 4 was problematic.

\section{What Else is New with Counter 5?}

The COUNTER Executive Board and Technical Advisory Board have been discussing additional considerations that may be of interest to the library community. They have been 
working with others to create a consortia reporting tool which is still in development. In the meantime, EBSCO Information Services has developed a way for small- and medium-sized consortia to view usage across libraries. Led by Oliver Pesch, EBSCO has released the SUSHI Harvester for Multi-Site Libraries or the R5 Harvester. The R5 Harvester is a Microsoft Access tool which allows consortia to gather the COUNTER reports together for all of their affiliated libraries using COUNTER_SUSHI to simplify the process. ${ }^{1}$

\section{COVID-19 Update}

Many publishers removed their paywall for portions of their content between March and May or June 2020 in response to COVID-19. SCELC (Statewide California Electronic Library Consortium) has compiled a list of publishers who opened content. ${ }^{2}$ The extent and manner in which each library's patrons used this open content may affect the usage statistics for this period. Because many users were working from home (outside their institutional IP range), their usage of open content cannot be attributed to their institution if they were visiting publisher platforms directly without authenticating via their institution's proxy or portal. As a result, libraries may see a downturn in usage in their COUNTER reports during this time. Emery suggests that librarians make a notation and consider this situation when evaluating their 2020 usage data.

\section{Additional COUNTER Resources}

COUNTER has developed Foundation Classes that have become very popular. Each Class plays for ten to fifteen minutes and covers a different aspect of Release 5 reports and metrics. They are available on the COUNTER YouTube channel, to which individuals can subscribe. ${ }^{3}$ These courses are a good place to start for developing a deep understanding for working with these reports and metrics. COUNTER is also in the process of creating a manual for librarians. Module 1 focuses on e-book metrics and is currently available for download. ${ }^{4}$ 
Module 2, which is in the editing phase, will cover e-journal metrics. It will be forthcoming in summer 2020.

\section{Selected Questions from the Audience}

Question: Regarding the Unique_Item_Requests metric: If a person is online for a long time and clicks on the same item again, is it counted again or is that corrected?

Answer: That is corrected in Release 5. If the user closes their browser or leaves the website and redirects elsewhere, then returns to it and clicks the same thing, it will be counted twice. There is no way for COUNTER to account for that, but if the user has remained on the same Web page and clicked twice within the same session, it will not be counted twice. It will only count once.

Question: I used to be able to easily add the total number of article downloads, but now I can't because they list both unique and total as you mentioned. How would this be done in Release 5 reports?

Answer: COUNTER has a Foundation Class on sorting the reports, so that you can then readily total those figures. I recommend looking at the Foundation Classes. ${ }^{5}$

Question: Have you seen any interesting uses of the COUNTER 5 data that has surprised you?

Answer: We are just in the stage of gathering our annual usage statistics and looking at them at Portland State. However, it has been surprising to see the amount of Open Access use that occurs for certain titles and certain journal platforms and how that impacts the overall usage of the content.

Question: Is there a good Foundation Class using pivot tables in Excel?

Answer: Yes, I recommend COUNTER Foundation Class 10: Working with Counter 5 Reports in Microsoft Excel. ${ }^{6}$ 
Question: Do you have to be an EBSCO library to use the R5 Harvester?

Answer: No, you do not. Consult the COUNTER R5 Harvester tool manual. ${ }^{7}$

Question: Could the exclusion of Open Access journals be a disincentive to aggregators to grow the number of Open Access journals in the package or collection? Isn't it a valuable service to integrate Open Access with subscribed materials?

Answer: It $i$ an advantage for aggregators to include it. I think it becomes contingent upon a library to really determine how they want to evaluate an aggregator and if they still want to evaluate them in the same way they did previously. When I showed the example from The Royal Society report that listed controlled access and Gold OA access; that was for a journal platform. At my institution [Portland State University], we do not look at the TR_JR report for aggregators, we look at the Database Reports, which give different count information that does not look specifically at titles. I think it really depends on what you choose to evaluate in terms of aggregators at your institution, as to how much of an impact that is going to have.

Question: In the report that includes Open Access and controlled access, is each title identified as being Open Access or controlled?

Answer: That is an Item Report, so it does not contain counts for each title; it is actually counting each article use. Because of the hybrid journal situation, there could be one journal that has a number of articles behind a paywall while others are Open Access. The count in that report is reported at the more discrete article level as opposed to the journal level. 
Question: Are there recommended guidelines for how to report usage, especially in terms of dealing with some providers presenting usage in COUNTER 4 while others are providing COUNTER 5?

Answer: In the Friendly Guide, there is a chart that shows comparisons. ${ }^{8}$ COUNTER recognizes that not everyone has moved to Release 5 at this point. Unfortunately, they do not have an entire translation between Release 4 and Release 5. However, as mentioned earlier in the session, library demand can lead to publisher and vendor action in terms of transitioning to Release 5.

\section{NOTES}

1. Oliver Pesch, “COUNTER R5 SUSHI Harvester for Multisite Libraries: Simplifying COUNTER Report Harvesting for Consortia and Other Multi-site Institutions" (Ipswich, MA: EBSCO Information Services, 2020), accessed July 29, 2020. URL: https://www.projectcounter.org/wpcontent/uploads/2020/05/Sushi_Harvester_20200515.pdf.

2. “Outstanding COVID-19 Resources for Libraries," SCELC, accessed June 10, 2020. URL: https://scelc.org/news/covid-19-resources.

3. “COUNTER Foundations Classes," YouTube, accessed June 9, 2020. URL: https://www.youtube.com/playlist?list= PL9OAw4zLhfa0bzMLXAfJXGhlbGjG8y_fg.

4. John Hendry, "Release 5 Manual for Librarians: Books: Understanding Metrics and Standard Views; Module 1: Book Usage" (Winchester, UK: COUNTER, 2020), accessed July 28, 2020. URL: https://www.projectcounter.org/wpcontent/uploads/2020/04/Release_5_Librarians_PDF_ 20200428.pdf. 
5. "COUNTER Foundations Classes."

6. Kornelia Junge, “COUNTER Foundation Class 10: Working with COUNTER 5 Reports in Microsoft Excel," YouTube, accessed July 31, 2020. URL: https://youtu.be/AU_DBLi4hSo.

7. Pesch, "COUNTER 5 SUSHI Harvester for Multisite Libraries."

8. Tasha Mellins-Cohen, "The Friendly Guide to Release 5 for Librarians" (Winchester, UK: COUNTER, 2018), accessed July 29, 2020. URL: https://www.projectcounter.org/wpcontent/uploads/2019/05/Release_5_Librarians_20190509-Revised-Edition.pdf

\section{ACKNOWLEDGMENTS}

COUNTER wishes to thank NASIG for being members of COUNTER and supporting the work that they do.

\section{CONTRIBUTOR NOTES}

Jill Emery is the Collection Development \& Management Librarian, Portland State University, Portland, Oregon.

Lorraine Estelle is the Director of Project COUNTER, London, United Kingdom.

Stephanie J. Adams is the Electronic Resources Librarian, Tennessee Technological University, Cookeville, Tennessee. 
Table 1.

\begin{tabular}{|l|c|l|c|}
\hline \multicolumn{2}{|c|}{ Release 4 Counts } & \multicolumn{2}{c|}{ Release 5 Counts } \\
\hline $\begin{array}{l}\text { Reporting Period HTML } \\
\text { Successful Requests }\end{array}$ & 1 & Total_Item_Investigations & 3 \\
\hline $\begin{array}{l}\text { Reporting Period PDF } \\
\text { Successful Requests }\end{array}$ & 1 & Unique_Item_Investigations & 1 \\
\hline $\begin{array}{l}\text { Reporting Period Total } \\
\text { Successful Requests }\end{array}$ & 2 & Total_Item_Requests & 2 \\
\hline & & Unique_Item_Requests & 1 \\
\hline
\end{tabular}

Table 1 COUNTER Release 4 and 5 Comparison 
Table 2.

\begin{tabular}{|l|c|}
\hline \multicolumn{1}{|c|}{ Metric } & Count \\
\hline Total_Item Investigations & 5 \\
\hline Unique_Item_Investigations & 3 \\
\hline Total_Item_Requests & 4 \\
\hline Unique_Item_Requests & 3 \\
\hline Unique_Title_Investigations & 1 \\
\hline Unique_Title_Requests & 1 \\
\hline
\end{tabular}

Table 2 COUNTER Release 5 E-book Counts 
Figure 1.

\begin{tabular}{|l|l|l|l|l|l|l|}
\hline Title & Platform & ISBN & Data_Type & $\begin{array}{l}\text { Section } \\
\text {-Type }\end{array}$ & Metric_Type & $\begin{array}{l}\text { Reporting_ } \\
\text { Period_ } \\
\text { Total }\end{array}$ \\
\hline $\begin{array}{l}\text { Big book } \\
\text { of } \\
\text { chapters }\end{array}$ & $\begin{array}{l}\text { Platform } \\
\text { A }\end{array}$ & $\begin{array}{l}978-0- \\
300-14 \\
424-6\end{array}$ & Book & Book & $\begin{array}{l}\text { Total_Item_ } \\
\text { Requests }\end{array}$ & 1 \\
\hline $\begin{array}{l}\text { Big book } \\
\text { of } \\
\text { chapters }\end{array}$ & $\begin{array}{l}\text { Platform } \\
\text { A }\end{array}$ & $\begin{array}{l}978-0- \\
300-14 \\
424-6\end{array}$ & Book & Book & $\begin{array}{l}\text { Unique_Item } \\
\text {-Requests }\end{array}$ & 1 \\
\hline $\begin{array}{l}\text { Big book } \\
\text { of } \\
\text { chapters }\end{array}$ & $\begin{array}{l}\text { Platform } \\
\text { A }\end{array}$ & $\begin{array}{l}978-0- \\
300-14 \\
424-6\end{array}$ & Book & Book & $\begin{array}{l}\text { Unique_Title } \\
\text { Requests }\end{array}$ & 1 \\
\hline
\end{tabular}

Figure 1 Platform A Sample TR_B1 
Figure 2.

\begin{tabular}{|l|l|l|l|l|l|l|}
\hline Title & Platform & ISBN & Data_Type & $\begin{array}{l}\text { Section } \\
\text {-Type }\end{array}$ & Metric_Type & $\begin{array}{l}\text { Reporting_ } \\
\text { Period__ } \\
\text { Total }\end{array}$ \\
\hline $\begin{array}{l}\text { Big book } \\
\text { of } \\
\text { chapters }\end{array}$ & $\begin{array}{l}\text { Platform } \\
\text { B }\end{array}$ & $\begin{array}{l}978-0- \\
300-14 \\
424-6\end{array}$ & Book & Chapter & $\begin{array}{l}\text { Total_Item_ } \\
\text { Requests }\end{array}$ & 27 \\
\hline $\begin{array}{l}\text { Big book } \\
\text { of } \\
\text { chapters }\end{array}$ & $\begin{array}{l}\text { Platform } \\
\text { B }\end{array}$ & $\begin{array}{l}978-0- \\
300-14 \\
424-6\end{array}$ & Book & Chapter & $\begin{array}{l}\text { Unique_Item } \\
\text {-Requests }\end{array}$ & 27 \\
\hline $\begin{array}{l}\text { Big book } \\
\text { of } \\
\text { chapters }\end{array}$ & $\begin{array}{l}\text { Platform } \\
\text { B }\end{array}$ & $\begin{array}{l}978-0- \\
300-14 \\
424-6\end{array}$ & Book & Chapter & $\begin{array}{l}\text { Unique_Title } \\
\text {-Requests }\end{array}$ & 1 \\
\hline
\end{tabular}

Figure 2 Platform B Sample TR_B1 